Medical Sciences

ISSN : 1308-7312 (NWSAMS)

ID: $2020.15 .1 .1 B 0086$
Status : Review

Received: 07.06 .2019

Accepted: 15.10 .2020

Özlem Coşkun, Özlem Öztopuz

Çanakkale Onsekiz Mart University, Çanakkale-Turkey ozlemcoskun@comu.edu.tr; ozlemoztopuz@comu.edu.tr

\begin{tabular}{l|l|l|l}
\hline \hline DOI & \multicolumn{3}{|l}{$\mathrm{http}: / / \mathrm{dx} . \mathrm{doi} .0 \mathrm{rg} / 10.12739 / \mathrm{NWSA} .2020 .15 .1 .1 \mathrm{~B} 0086$} \\
\hline ORCID ID & $0000-0002-0741-5001$ & $0000-0002-1373-6311$ \\
\hline \multicolumn{2}{l}{ CORRESPONDING AUTHOR } & Özlem Coşkun \\
\hline \hline
\end{tabular}

\title{
ELECTROPHORESIS APPLICATIONS USED IN MEDICINE
}

\section{ABSTRACT}

Clinical analysis distinguishing between the characteristics of healthy and pathological conditions, the researcher to solve the mystery of the disease and to provide the treatment of the disease in a short time is very important to save human life. Electrophoresis routine biochemistry, hematology, or urinalysis is one of the basic diagnostic methods commonly used in the world to obtain vitally important information. Nonspecific changes in electrophoretic patterns are associated with patient clinical data electrophoresis, it is very valuable in determining the diseases which cannot be detected by routine diagnostic studies. Many diseases such as liver, renal pathological disorders, inflammation, proteinemia, multiple myeloma, and macroglobulinemia can be diagnosed by electrophoresis. Recent developments in electrophoresis technology will be the miniaturization and portability of systems. With the development of technology, it is possible to perform electrophoresis with programming that enables automatic execution of computerized robotic and electrophoresis protocols. Large research is carried out to improve the systems used by different working groups, especially the automatic electrophoresis system. The methods explored and developed are mainly aimed at increasing the efficiency, reproducibility and accuracy of the separation process. The aim of this review is to emphasize the general features of electrophoresis method, clinical diagnostic applications and future potential.

Keywords: Electrophoresis, Electrophoresis in Diagnosis, Clinical Applications, Clinical Analysis, Electrophoresis Types

\section{INTRODUCTION}

Clinical analysis is very important in terms of improving the quality of life by providing rapid medical treatment [1]. In order to solve the problems encountered in clinical medicine, clinical analyzes should be performed by experts to obtain accurate results at the lowest possible cost. Numerous electrophoretic methods are routinely used in various clinical laboratory [2]. Electrophoresis is a sort of separation technique based on the differential migration properties of charged molecules in an electric field. It is an analytical method commonly used in molecular biology, biochemistry and medicine [3]. For qualitative and preparatory purposes, electrophoretic methodologies are widely used in biological research and are well defined in most research laboratories as a long-term integral analytical tool [4]. Electrophoretic methods are important applications used in the identification of many diseases including biochemistry, gene technology, nucleic acid and protein sequencing, cancer in recent years. Electrophoresis is a common technique used in almost any field of basic or applied biomedical research for

\section{How to Cite:}

Coşkun, Ö. and Öztopuz, Ö., (2020). Electrophoresis Applications Used in Medicine, Medical Sciences (NWSAMS), 15(1):12-25, DOI: 10.12739/NWSA.2020.15.1.1B0086. 
separation by charge and/or mass. In electrophoresis, molecules such as proteins, enzymes, lipoproteins are separated using various support media (paper, cellulose acetate, starch, agarose and polyacrylamide) depending on the type of electrophoresis. Factors affecting mobility are the size, shape, ionic strength of the solution, viscosity and temperature of the medium [5 and 6]. Electrophoresis is frequently used to identify diseases that cannot be detected by routine diagnostic studies, and to identify and follow pathological conditions. Electrophoretic patterns, routine biochemistry analysis, hematology applications or urine analysis, especially in the separation of serum proteins have been widely used in medicine for many years [7]. Evaluation of serum proteins and their electrophoretic models are well-established laboratory method for the diagnosis, pathological detection and monitoring of many diseases. The results of serum protein electrophoresis are one of the most useful diagnostic pathways in a wide range of diseases, including infectious and inflammatory diseases, renal or gastrointestinal disorders, immunodeficiency states as well as paraproteinases caused by lymphoid or neoplasia [8]. Since the incorporation of electrophoresis into the scientific field, many changes and improvements have been made to the system in terms of analysis and efficiency. From basic paper electrophoresis to highly advanced automatic microchip electrophoresis system, each different system has its own unique functionality and unique application. With the development of technology, it is possible to perform electrophoresis with programming that enables automatic execution of computerized robotic and electrophoresis protocols [9].

\section{RESEARCH SIGNIFICANCE}

Electrophoresis is a widely used technique based on the use of electric current in diagnosis and biomedical research. Today, many electrophoresis techniques are used for routine or research purposes. Electrophoresis detection of many diseases that cannot be detected by routine diagnostic methods makes the method even more important. This review provides information about some electrophoresis techniques used in medicine. The advantages of recent developments in electrophoresis technology have been evaluated with current literature.

\section{SOME ELECTROPHORESIS TYPES USED IN CLINIC}

Some electrophoresis methods used in clinical investigations are summarized in the table.

Table 1. Electrophoresis Types Used in Clinic

\begin{tabular}{|l|l|c|}
\hline Electrophoresis Types & Clinic Applications & References \\
\hline $\begin{array}{l}\text { Polyacrylamide Gel } \\
\text { Electrophoresis }\end{array}$ & Abnormal Serum or Urine Protein & 10 \\
\hline Agarose Gel Electrophoresis & $\begin{array}{l}\text { Serum Proteins, Hemoglobin Variants, } \\
\text { Isoenzymes, Lipoprotein Fractions }\end{array}$ & 13 \\
\hline $\begin{array}{l}\text { Pulsed-Field Gel } \\
\text { Electrophoresis }\end{array}$ & $\begin{array}{l}\text { Chromosomal DNA, Many Bacterial } \\
\text { Species Dausing } \\
\text { Antimicrobial Susceptibility Testing, } \\
\text { Serotyping and Genome Sizes }\end{array}$ & $19-21$ \\
\hline Isoelectric Focusing & Monoclonal Antibody & 24 \\
\hline $\begin{array}{l}\text { Two Dimensional } \\
\text { Electrophoresis }\end{array}$ & Proteomics Analysis, & 28 \\
\hline Capillary Electrophoresis & Genomic And Pharmaceutical Fields & 38 \\
\hline Microchip Electrophoresis & $\begin{array}{l}\text { Genotyping, Mutation Analogical Tests } \\
\text { Immunologich }\end{array}$ & 45 \\
\hline Immunoelectrophoresis & Immunoglobulin & 48 \\
\hline $\begin{array}{l}\text { Immunofixation } \\
\text { Electrophoresis }\end{array}$ & Monoclonal Immunoglobulin & 49 \\
\hline Hemoglobin Electrophoresis & Hemoglobin Variants & 28 \\
\hline
\end{tabular}




\subsection{Polyacrylamide Gel Electrophoresis (PAGE)}

Polyacrylamide Gel Electrophoresis is the most common type of electrophoresis. It is a low-cost, reproducible and rapid method for quantifying, comparing and characterizing protein, peptides and small molecular weight nucleic acids [10]. Separation of the gel power and molecular weight depend on the acrylamide/bisacrylamide ratio. Polymerization of these two substances creates pores in the gel (Figure 1). PAGE is used to control the purity of proteins, determination of molecular weights and concentration [11].

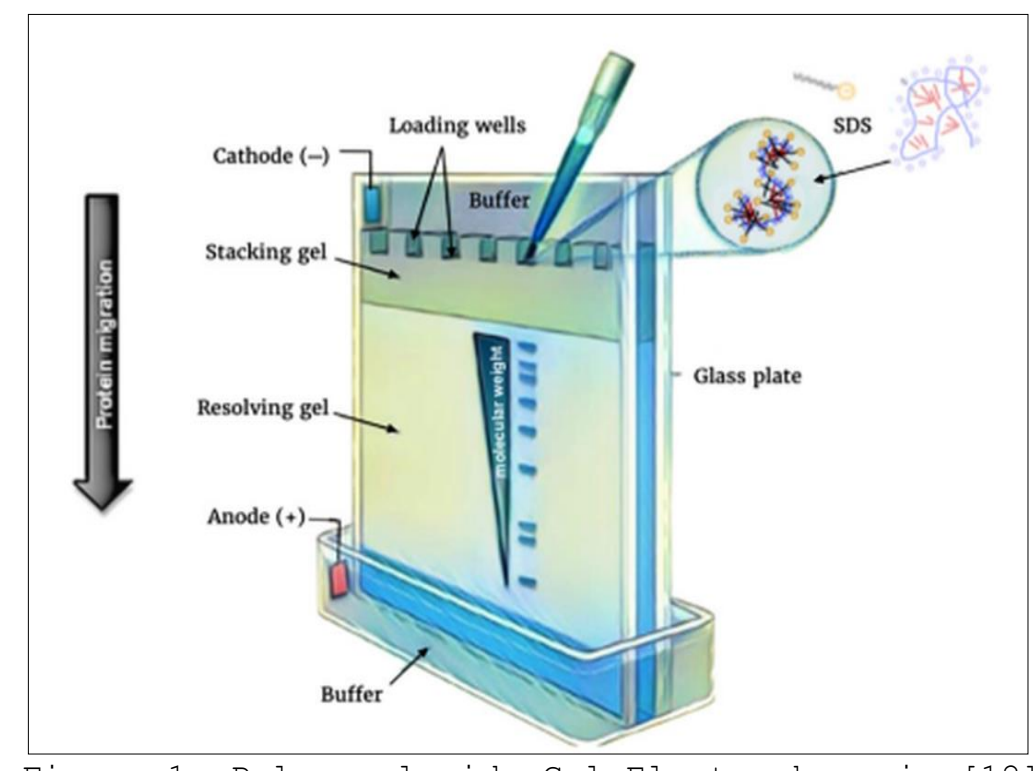

Figure 1. Polyacrylamide Gel Electrophoresis [12]

\subsection{Agarose Gel Electrophoresis (AE)}

Agarose gel electrophoresis has been successfully applied for the analysis of serum proteins, hemoglobin variants, isoenzymes, lipoprotein fractions. It is usually used to separate DNA or RNA fragments of different lengths (Figure 2). In this method, molecules are separated according to their length, size and structure [13]. Agarose gel electrophoresis is widely used in various fields of biotechnology, biomedical and forensic laboratories. It is also a technique used routinely in clinical laboratories to detect protein abnormalities in various biological fluids (serum, urine, cerebrospinal fluid) [14].

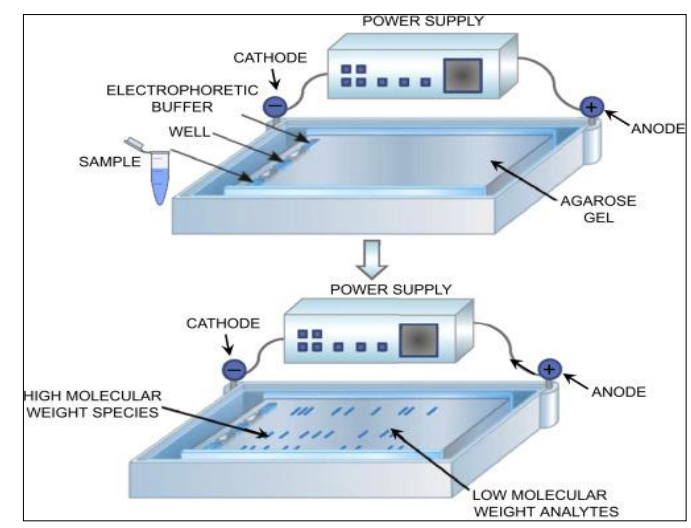

Figure 2. Agarose Gel Electrophoresis [15] 


\subsection{Pulsed-Field Gel Electrophoresis (PFGE)}

DNA molecules of large molecular weight cannot be separated by classic electrophoresis. PFGE separates chromosomal DNA from many living species utterly, including bacteria, viruses and mammals, from the parasite chromosome to the yeast chromosome [16-18]. The most significant difference of PFGE from other electrophoresis techniques is that the applied electric field is not constant (Figure 3). PFGE is used for characterization of many bacterial species causing diseases, antimicrobial susceptibility testing, serotyping and genome sizes [1921].

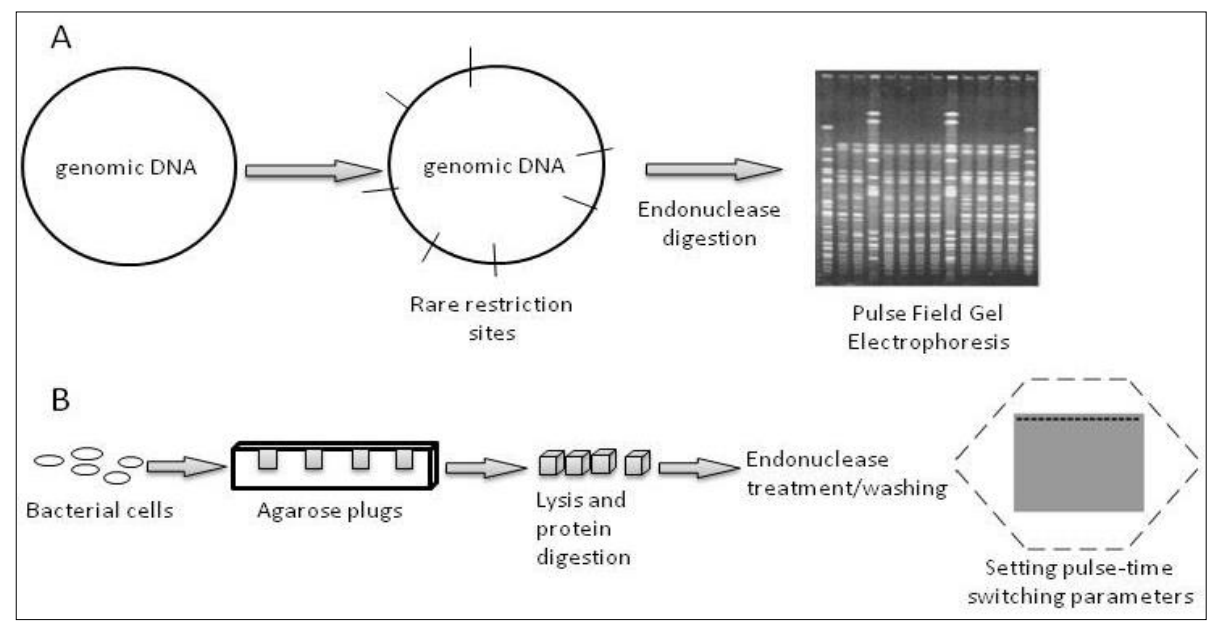

Figure 3. Schematin presentation of Pulsed-Field Gel Electrophoresis [22]

\subsection{Isoelectric Focusing (IEF)}

Isoelectric focusing is based on the separation of proteins according to isoelectric points. In this method, the $\mathrm{pH}$ gradient is formed by low molecular weight ampholites. In the gel, a decreasing pH gradient occurs from the anode to the cathode (Figure 4). Proteins migrate to a $\mathrm{pH}$ (pI=isoelectric point) where the net charge on the gel is zero and stop at this point [23 and 24].

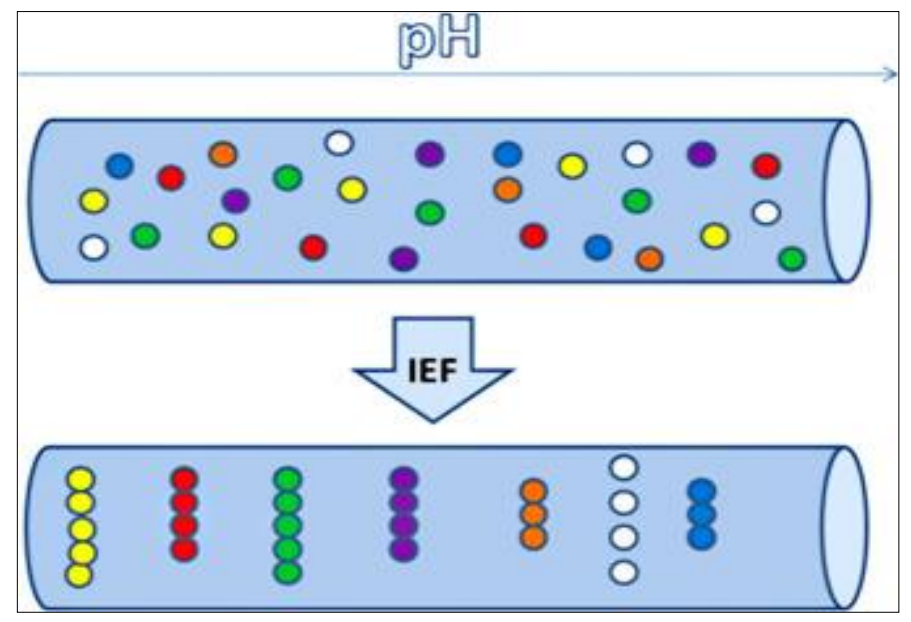

Figure 4. Isoelectric focusing [25] 


\subsection{Two-Dimensional (2DE) Gel Electrophoresis}

Two-dimensional polyacrylamide gel electrophoresis (2-DE) is considered to be a powerful tool for separating complex protein mixtures from tissues, cells or other biological samples. With this method, hundreds of thousands of proteins are separated in a gel [26]. Twodimensional electrophoresis makes it possible to obtain important diagnostic information from hundreds of possible protein peaks. This method uses IEF (isoelectric focusing) in the first dimension. In the second dimension, molecular weight-dependent SDS-PAGE(Sodium Dodecyl Sulfate-Polyacrylamide Gel Electrophoresis) is used (Figure 5) [27]. In this method, computer support is needed in order to interpret or compare the points indicating the presence of a large number of proteins on the gel after staining. A complete disease diagnosis can be obtained by analyzing proteins present in both normal and diseased cells or tissues. Proteomics defines the structure, location, amount, post-translational modifications, functions of tissues and cells of all proteins and their interaction with other proteins and macromolecules. It is the main method for proteomics. With this method, even small changes in protein amounts can be analyzed. Thus, new proteins that arise in pathological conditions can be readily identified. The comparison can be made between two different situations (normal and disease, old and young) with expression proteomics [28]. 2D is used for profiling in proteiomics studies, and the most important function of this method is the different representations of proteins expressed in different conditions (Figure 5).

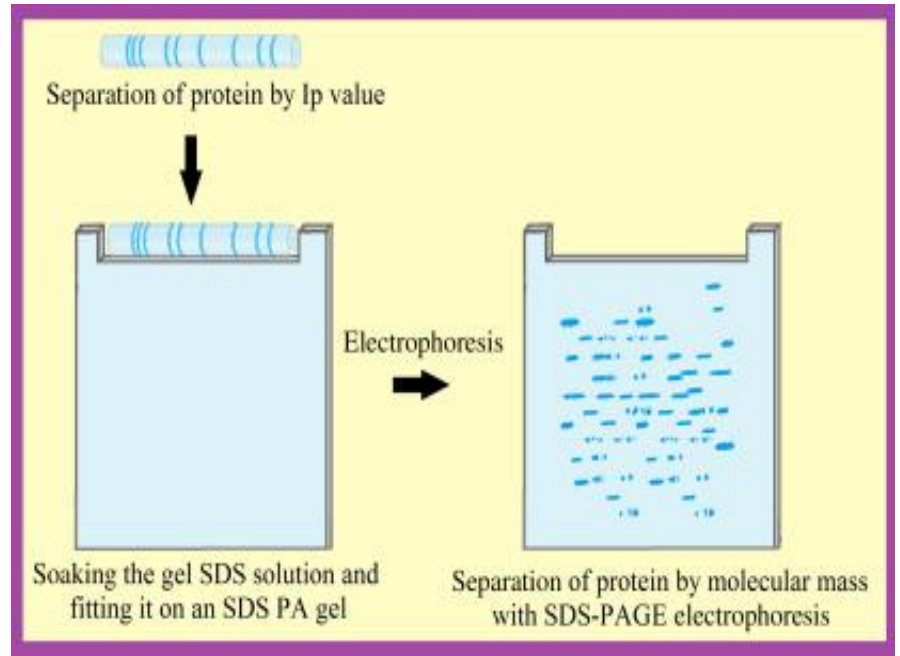

Figure 5. Two-Dimensional (2DE) gel electrophoresis [29]

Many research has been done on the biological and clinical applications of proteomics[30].Proteomic technology is used to systematically analyze and quantify the relationships, structure and function of proteins in cells, tissues and body fluids in different conditions such as health and disease [31]. The goals of proteomics studies include early diagnosis of diseases, identification of different stages, and the development of new and effective biomarkers for better evaluation of therapeutic applications. The characteristics of an ideal biomarker should be specific for a particular disease, enable early diagnosis of this disease, change in the amount of disease development and change, allow the follow-up of the drug treatment, work on easily obtainable biological material, and repeatable and easily applicable method (Figure 6) [32]. 


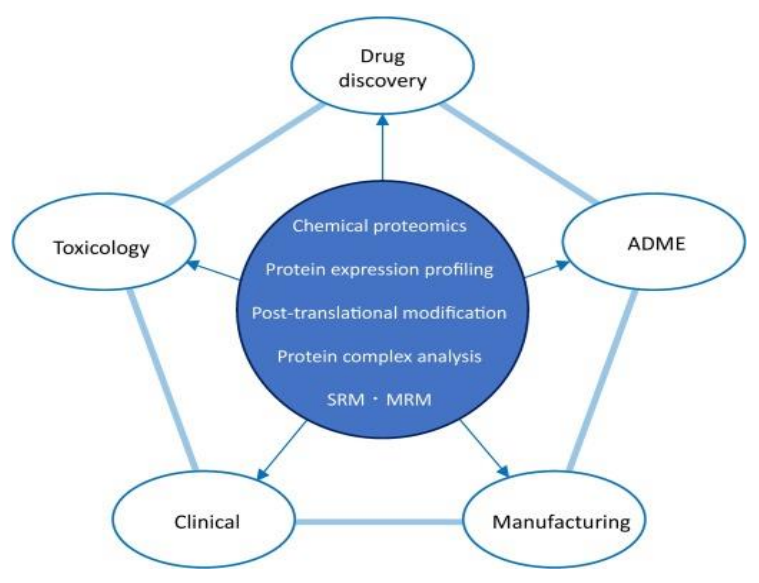

Figure 6. Applications of Two-Dimensional (2DE) Gel Electrophoresis [33]

\subsection{Capillary Electrophoresis (CE)}

The capillary electrophoresis technique and equipment are quite different from other electrophoresis techniques. The system consists of a thin silica capillary tube, two electrolyte buffer chambers, a high voltage power supply and a detector associated with a data evaluation unit (Figure 7). The advantage of working in narrow diameter tubes is the elimination of heat generated by other electrophoretic methods [34 and 35]. Capillary electrophoresis is an analytical technique used for the separation and quantification of a wide variety of molecules based not only on charge but also on size, hydrophobicity and stereospecificity [36]. Capillary electrophoresis is an analytical method used in genetic analysis, drug discoveries, analysis of drug impurities, including anticancer drugs, and protein characterization [37]. The clinical advantage of capillary electrophoresis is that application, flexibility and the ability to analyze compounds of diagnostic importance. This technique allows rapid and low sample volume funtion in clinical laboratories in genomic and pharmaceutical fields, and has the advantage of being quantitative and automated as well as separating compounds that are difficult to distinguish by conventional methods [38].

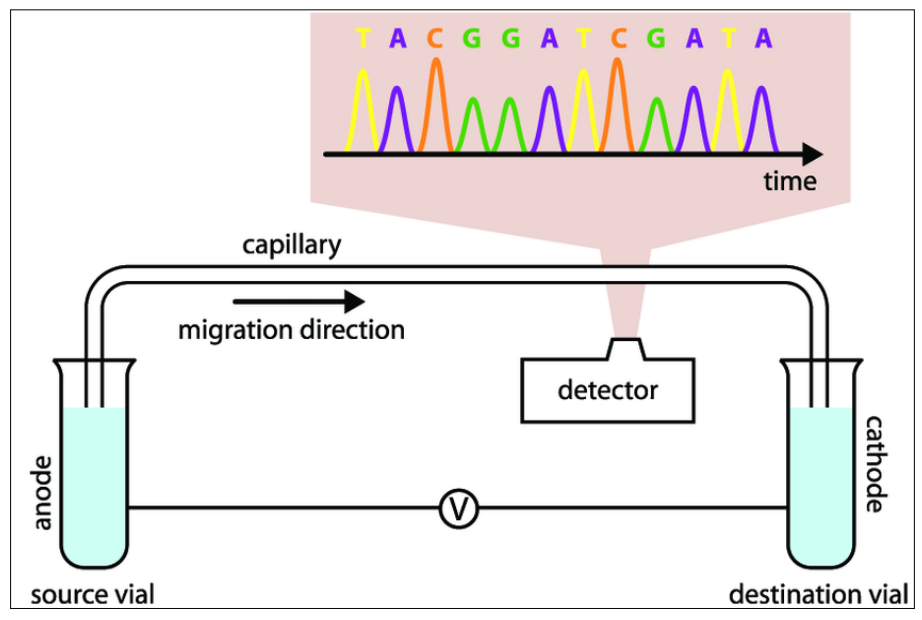

Figure 7. Capillary Electrophoresis [39]

\subsection{Microchip Electrophoresis (ME)}

Microchip electrophoresis systems are superior to other systems because they contain a large number of microchannels that allow the 
experiments to be carried out quickly and efficiently. It is also a fully automated system that allows minimum manuel use from sample processing to data analysis [40]. Since highly sensitive methods are required for $\mathrm{ME}$, laser-induced fluorescence and electrochemical detection methods are used. Its superiority over other techniques is better heat dissipation, automation, speed, flexibility and simplicity. The key element in clinical diagnosis is the interpretation of the data obtained by analysis of patient samples. Although standard clinical diagnostic methods require days to retrieve patient data, ME can reduce outcome up to minutes, accelerating the transition to treatment (Figure 8). Microchip eletrophoresis has been widely used in clinical diagnosis for genotyping, mutation analysis, immunological tests and small molecule detection. This technique is used in the diagnosis of diseases such as cancer, immune disorders, neurological diseases, genetic disorders, cardiovascular diseases, infectious diseases and pathogens, organ and functional disorders, diabetes and pancreatic dysfunction and reproductive disorders. It has been reported that ME provides high-speed analysis with minimum sample for both patients and clinicians in the diagnosis in the last decade [41].

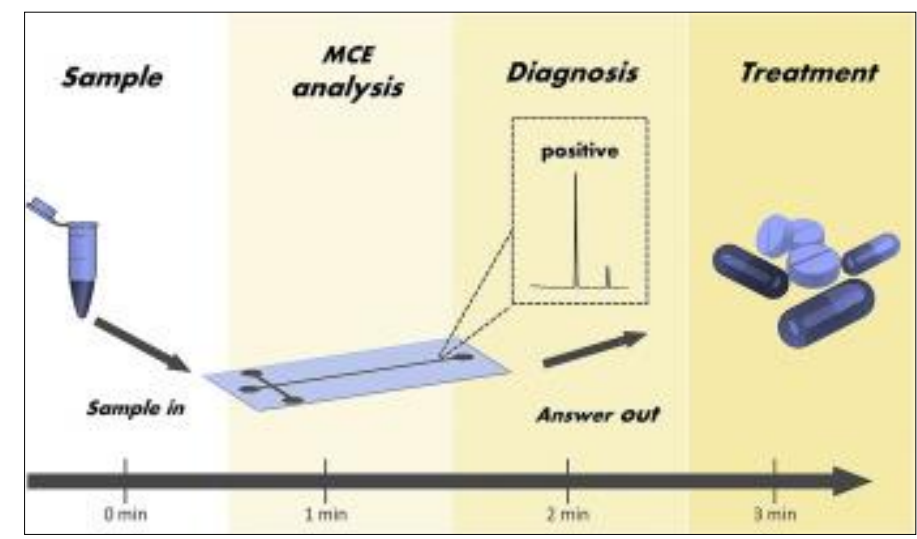

Figure 8. Microchip Electrophoresis [42]

\subsection{Immunoelectrophoresis (IF)}

Serum protein electrophoresis is widely used for the detection and identification of paraproteins, as well as changes in proteins associated with inflammation, liver or kidney disease in clinical laboratories [43]. It is used for the diagnosis and follow-up of paraproteinemias. Both protein concentration changes and structural abnormalities can be detected by immunoelectrophoresis, which shows monoclonal protein production in serum protein electrophoresis (Figure 9). Immunoelectrophoresis analysis involves two consecutive procedures. 1Separation of proteins in the mixture by agarose gel electrophoresis 2Antiserum added to the separated protein to show antigen antibody precipitates. Antigen-antibody precipitation bands are formed after simultaneous diffusion. The structure and position of the precipitation bands is characteristic for each protein, compared with control sera [44]. 


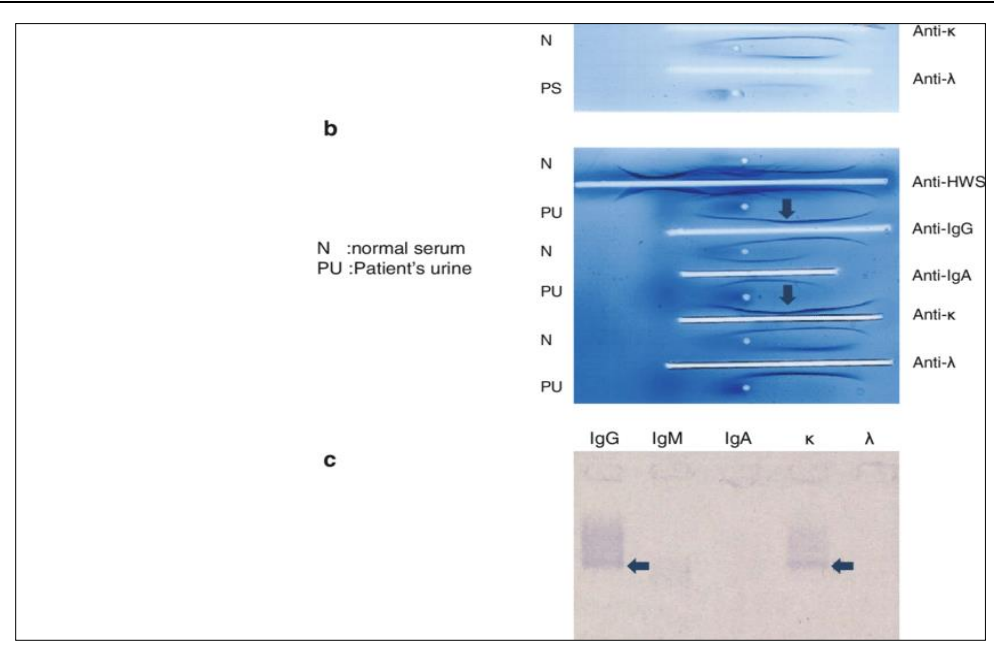

Figure 9. Serum immunoelectrophoresis showing the immunoglobulin G kappa monoclonal band [45]

\subsection{Immunofixation Electrophoresis (IFE)}

Immunofixation electrophoresis is a gold standard biochemical technique used to guide the diagnosis, follow-up and treatment of monoclonal gamopathies. IFE is a preferred method for the diagnosis and follow-up of multiple myeloma, paraproteinemias in medical research, genetic studies and clinical laboratory applications (Figure 10). Immunofixation electrophoresis is a two-stage;

- Step 1: Separation of proteins in agarose gel

- Step 2: Immunosuppression; serum, urine, CSF (cerebrospinal fluid) or other body fluids can be used [46].

The presence of a monoclonal protein detected in serum protein electrophoresis, an indeterminate narrow band, hypogammaglobulinemia, increased beta or gamma fraction is considered abnormal. In this case, serum and urine IFE assessment is required to confirm and identify the monoclonal protein.
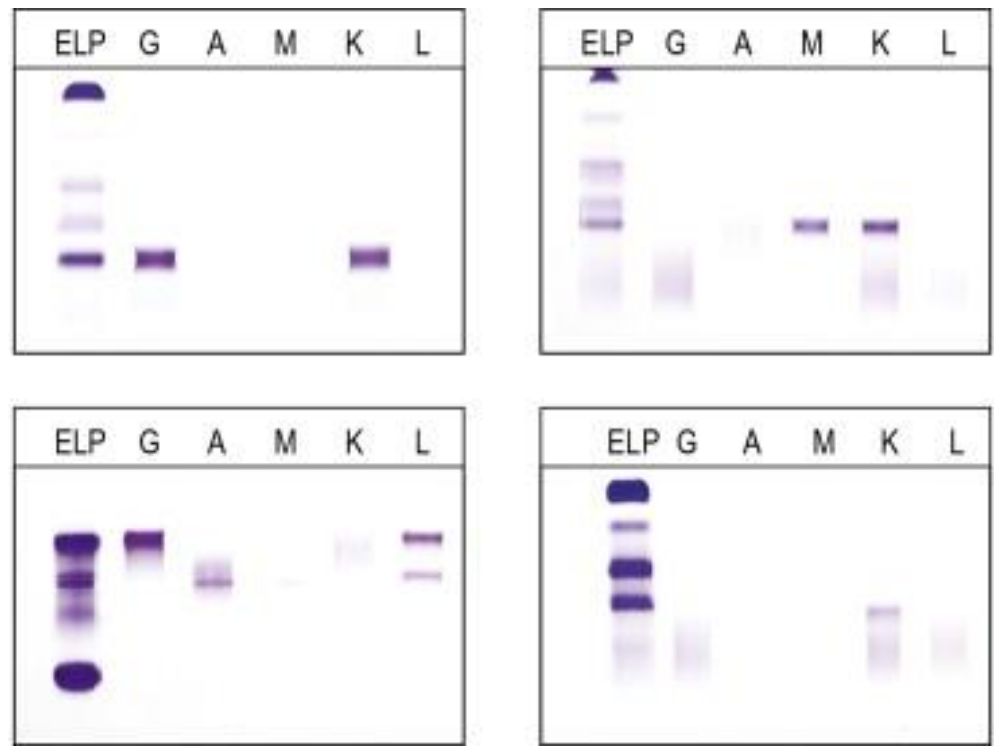

Figure 10. Immunofixation electrophoresis(IFE) on serum from 4 patients [47] 
Since immunofixation can be used for the identification and typing of monoclonal immunoglobulins, it has replaced the usual immunoelectrophoresis in many laboratories. The reason why IFE is widely used compared to immuno-electrophoresis is related to the many advantages it provides in the process stage. IFE helps to make a more accurate conclusion about doubtful cases that cannot be clearly identified by normal protein electrophoresis. Changes in serum proteins may be indicative of nonspecific pathological processes or may represent potential diagnostic markers of certain pathological conditions [48].

\subsection{Hemoglobin Electrophoresis (HE)}

Hereditary abnormalities encountered in hemoglobin synthesis are grouped under two main groups. These are abnormal hemoglobin variants and thalassemia (Figure 11). Hemoglobin electrophoresis is used to identify anomalies. HB electrophoresis is very easy, sensitive and fast method in pH: 8.5 using agarose gel with cellulose acetate membrane in routine analysis.

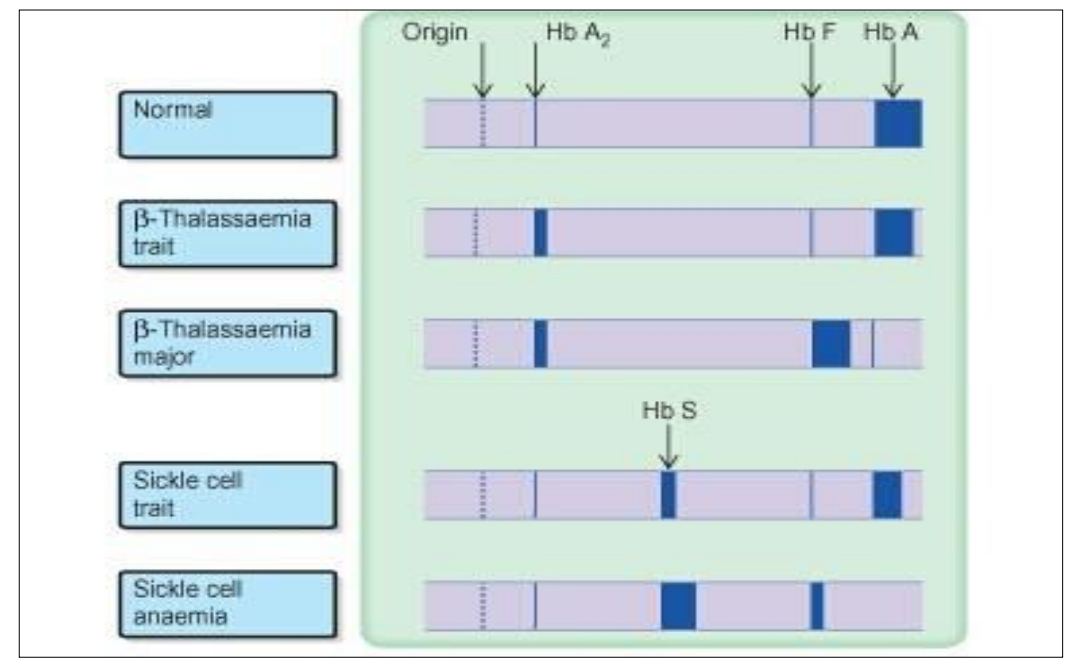

Figure 11. Hemoglobin electrophoresis [49]

\subsection{Automatic Electrophoresis System}

With the development of technology, it is now possible to perform electrophoresis using programs that provide computerized robotic electrophoresis systems [50]. High efficiency protein analysis can be performed with automatic 2D capillary electrophoresis system. In the Human Genome Project, an automated electrophoresis system was used to detect changes in the human gene. Automated electrophoresis systems are extremely sensitive to detect conformation polymorphism in genetic samples. High efficiency protein analysis can be performed with automatic 2D capillary electrophoresis system. In the Human Genome Project, an automated electrophoresis system was used to detect changes in the human gene. Automated electrophoresis systems are extremely sensitive to detect conformation polymorphism in genetic samples [51 and 52]

\subsection{Future Electrophoretic Developments}

With the development of technology, it is possible to increase the speed and processing of the electrophoresis using fewer samples. Although electrophoresis technology is very advanced from the traditional electrophoresis system to the microchip electrophoresis system, an external power supply is still needed for electrophoresis [53). Electrophoresis without a power supply is not possible yet. Numerous patents have been received to improve efficiency with existing systems, 
such as using a different buffer system or gel type [54]. Research is continuing to improve the systems currently used by different research groups around the world, in particular the automatic electrophoresis system [55].

\section{DISCUSSION}

Electrophoretic techniques will continue to be applied in the clinical laboratory for many years. It will become increasingly important to select and apply the appropriate electrophoresis technique for specific separation problems. High-resolution electrophoretic methods can be applied to solve heterogeneous clinical problems and simplify the analytical process by fully automated electronic handling of data. Capillary electrophoresis is the best automation solution for all electrophoresis methods to detect nucleic acids by electrophoretic mobility. In addition to size characteristics, fluorescent labels give DNA fragments another feature for identification. CE, which requires minimal human intervention from sample loading to data analysis, not only saves a lot of labor, but also eliminates most human errors related to sample loading, data analysis and input. With capillary electrophoresis, great attention to detail, such as capillary location and gas flow rate of each test run, should be taken to reproduce the same results, as differences in settings will produce different results for the same experiment [56]. SDS polyacrylamide gel electrophoresis has proved to be an incredibly useful analytical method for determining the number and size of polypeptides in a sample. It has the ability to dissolve many individual proteins when done skillfully [57]. The potential to integrate many functions into a single device, minimal sample and reagent consumption, and the ability to analyze a wide variety of molecules make microchip electrophoresis an ideal candidate for nextgeneration separation technology that has an impact on a variety of aspects, including the pharmaceutical industry [58]. The combined use of many powerful new techniques makes the analysis of mammalian genes within reach. PFGE will play an important role in mapping the human genome. The PFGE technique will be useful to determine the degree of association between different strains of the same species. PFGE techniques for future applications may include separation of protein and nucleic acid sequences and DNA topology studies. PFGE allows physical mapping for almost all organisms [59]. Finally, Microchip electrophoresis is a promising new electrophoresis technology developed and tested for the detection of biomarkers in clinical specimens such as urine, serum, cerebrospinal fluid and saliva. For all that, microchip electrophoresis evolved from capillary electrophoresis, a promising miniaturization technology that is considered a hybrid form of electrophoresis and chromatography [60 and 61]. Electrophoresis is one of the most common techniques used for analytical and pharmaceutical separations. Electrophoresis technique is used in research and applied biomedical studies. Electrophoresis distinguishes clinically abnormalities such as dysproteinemia and paraproteinemia, it is also possible to identify physiological electrophoretic patterns in specific laboratory studies and to distinguish healthy ones. Thanks to this technique, there have been revolutionary developments in the detection and epidemiology of infectious diseases in recent years.

\section{CONCLUSION}

The development of electrophoresis systems is driven by advances in technology and also by the necessity of better and faster resolution of the results. Electrophoresis technology began at the beginning of the nineteenth century and is still in practice even after two centuries. Although the existing electrophoresis, equipment and style are performed 
in many different ways and methods, which are very different from the original design, the basic principle remains the same. Following the trends of changes in electrophoresis technology, the next step of development will be miniaturization and portability of systems.

\section{NOTICE}

This study was presented as an oral presentation in the "International Hippocrates Congress on Medical and Health Sciences (1-3 March 2019 Ankara/Turkey" and restructured.

\section{REFERENCES}

[1] Gostin, L.O., Levit, L.A., and Nass, S.J., (Eds.) (2009). Beyond the HIPAA Privacy Rule: Enhancing Privacy, Improving Health Through Research. National Academies Press.

[2] Tissot, J.D., Layer, A., Schneider, P., Forestier, F., and Henry, H., (2000). Gel Electrophoresis.

[3] Caballero, B., Trugo, L.C., and Finglas, P.M., (2003). Encyclopedia of Food Sciences and Nutrition. Academic. Burgess, R.R. and Deutscher, M.P., (Eds.) (2009). Guide to Protein Purification (Vol:463). Academic Press.

[4] Fesmire, J.D., (2019). A Brief Review of Other Notable Electrophoretic Methods. In Electrophoretic Separation of Proteins (pp:495-499). Humana Press, New York, NY.

[5] Gowenlock, A.H., McMurray, J.R., and McLauchlan, D.M., (1987). Separative Procedures, Electrophoresis. In: Varley's Practical Clinical Biochemistry. Heinman Medical Books, London. 69-81.

[6] Marshal, W.J., (1995). Clinical Chemistry. Mosby, London. 20112 .

[7] Vavricka, S.R., Burri, E., Beglinger, C., Degen, L., and Manz, M., (2009). Serum Protein Electrophoresis: an Underused but Very Useful Test. Digestion, 79:203-10.

[8] Tothova, C., Nagy, O., and Kovac, G., (2016). Serum Proteins and Their Diagnostic Utility in Veterinary Medicine: A Review. Veterinarni Medicina, 61:475-496.

[9] Chin, K.J., Yuen, K.H., Sieo, C.C., and Yiap, B.C., (2013). Electrophoresis: What does a Century old Technology Hold for the Future of Separation Science?.

[10] Judd, R.C., (1996). SDS-polyacrylamide Gel Electrophoresis of Peptides. In The Protein Protocols Handbook (pp:101-107).

[11] Laemmli, U.K., (1970). Cleavage of Structural Proteins during the Assembly of the Head of Bacteriophage T4. Nature., 227:680685 .

[12] Jalali, M., Saldanha, F.Y.L., and Jalali, M., (Eds.) (2017). Basic Science Methods for Clinical Researchers. Academic Press.

[13] Hames, B.D., (1998). Gel Electrophoresis of Proteins A Practical Approach Third Edition. Edited by School of Biochemistry and Molecular Biology.

[14] Giot, J.F., (2010). Agarose gel Electorphoresis-applications in Clinical Chemistry. JMB., 29:9-14.

[15] Drabik, A., Bodzoń-Kułakowska, A., and Silberring, J., (2016). Gel Electrophoresis. In Proteomic Profiling and Analytical Chemistry (pp:115-143).

[16] Nedelcu, S. and Watson, J.H.P., (2004). Size Separation of DNA Molecules by Pulsed Electric Field Dielectrophoresis. J. Phys. D: Appl. Phys., 37:2197-2204.

[17] Schwartz, D.C. and Cantor, C.R., (1984). Separation of Yeast Chromosome-sized DNAs by Pulsed Field Gradient Gel Electrophoresis. cell, 37 (1):67-75. 
[18] Gardiner, K., (1991). Pulsed Field Gel Electrophoresis. Analytical Chemistry., 63:658-665.

[19] Tejedor, J.L., Vela, A.I., Gibello, A., Casamayor, A., Dominguez, L., and Fernandez, J.F., (2011). A Genetic Comparison of Pig, Cow and Trout Isolates of Lactococcus garvieae by PFGE Analysis. Letters in Applied Microbiology., 53:614-19.

[20] Türe, M. and Altınok, ̇̇., (2013). Pulsed-Field Jel Elektroforez (PFGE) Metodu ve Akuatik Organizmalarda Kullanımı. Süleymen Demirel Üniversitesi Eğirdir Su Ürünleri Fakültesi Dergisi., $9: 44-54$.

[21] McEllistrem, M.C., Stout, J.E., and Harrison, L.H. (2000). Simplifield Protocol for Pulsed-Field Gel Electrophoresis Analysis of Streptococcus pneumoniae. Journal of Clinical Microbiology., 38:351-353.

[22] Bonofiglio, L., Gardella, N., and Mollerach, M. (2012). Application of Molecular Typing Methods to the study of Medically Relevant Gram-Positive Cocci. Gel ElectrophoresisAdvanced Techniques, 113.

[23] O'Farrell, P.Z., Goodman, H.M., and O'Farrell, P.H. (1977). High Resolution Two-Dimensional Electrophoresis of Basic as Well as Acidic Proteins. Cell.,12:1133-1142.

[24] Bollag, D.M., Rozycki, M.D., and Edelstein, S.J., (1996). Protein Methods, Wiley-Liss, New York.

[25] Ciborowski, P., Silberring, J., (Eds.). (2016). Proteomic Profiling and Analytical Chemistry: The Crossroads. Elsevier).

[26] Magdeldin, S., Enany, S., Yoshida, Y., Xu, B., Zhang, Y., Zureena, Z., and Yamamoto, T., (2014). Basics and Recent Advances of Two Dimensional-Polyacrylamide Gel Electrophoresis. Clinical proteomics, 11(1):16.

[27] Pláteník, J., (2008/2009). First Faculty of Medicine, Charles University in Praque Electrophoresis in Biochemistry.

[28] György, M.V., (2004). Proteomics Principles and Challenges. Pure Appl Chem., 76: 829-37.

[29] Hochstrasser, D.F., (1997). Clinical and Biomedical Applications of Proteomics. Proteome Research: New Frontiers in Functional Genomics., 187-220.

[30] Srinivas, P.R., Srivastava, S., Hanash, S., and Wright, G.L., (2001). Proteomics in Early Detection of Cancer. Clinical Chemistry., 47:1901-1911.

[31] Şanlıoğlu, A.D., (2016). Proteomiks ve Stratejileri. Bölüm 23.

[32] Yokota, H., (2019). Applications of Proteomics in Pharmaceutical Research and Development. Biochimica et Biophysica Acta (BBA) Proteins and Proteomics, 1867 (1):17-21.

[33] Chiu, D.T., Lillard, S.J., Scheller, R.H., Zare, R.N., Rodriguez-Cruz, S.E., Williams, E.R., Orwar, O., Sandberg, M., Lundqvist, J.A., (1998). Probing Single Secretory Vesicles with Capillary Electrophoresis. Science., 20;1190-3.

[34] Tristezza, M., Gerardi, C., Logrieco, A., and Grieco, F., (2009). An Optimized Protocol for the production of interdelta markers in Saccharomyces Cerevisiae By Using Capillary Electrophoresis. Journal of Microbiological Methods., 78:286-91.

[35] Chen, F.T.A., Liu, C.M., Hsieh, Y., Sternberg J., (1991). Capillary Electrophoresis-a New Clinical Tool. Clin. Chem., 37:14-19.

[36] Voet, D. and Voet, J.G., (1995). Biochem 2nd Edition.

[37] Petersen, J.R., Okorodudu, A.O., Mohammad, A., and Payne, D.A., (2003). Capillary Electrophoresis and Its Application in the Clinical Laboratory. Clin Chim Acta., 330:1-30. 
[38] Gauthier, M.G., (2008). Simulation of Polymer Translocation Through Small Channels: A molecular Dynamics Study and a New Monte Carlo Approach (Doctoral Dissertation, University of Ottawa (Canada).

[39] Hammond, A., (2001). Microchip-based Capillary Electrophoresis: Sequencing and Beyond. Bioresearcher Online.

[40] Wuethrich, A. and Quirino, J.P., (2019). Decade of Microchip Electrophoresis for Clinical Diagnostics - A review of 20082017. Analytica Chimica Acta., 1045:42-66.

[41] Kaneko, K., Seta, K., Soma, J., Kuwahara, T., Koizumi, M., Kikuchi, Y., and Yahata, K., (2014). Gamma 1-heavy Chain Deposition Disease Accompanied by IgG kappa in Serum, Urine, and Bone Marrow. CEN case reports, 3(1):44-48.

[42] Thadikkaran, L., Siegenthaler, M.A., Crettaz, D., Queloz, P.A., Schneider, P., and Tissot, J.D., (2005). Recent Advances in Blood-Related Proteomics. Proteomics, 5(12):3019-3034.

[43] Gupta, S., Comenzo, R.L., Hoffman, B.R., and Fleisher, M., (2005). National Academy of Clinical Biochemistry Guidelines for the Use of Tumor Markers in Monoclonal Gammopathies. Section $3: \mathrm{K}$.

[44] Ercan, M., Oğuz, E.,Uysal, S., Sezer, S., Topçuoğlu, C., and Yılmaz, F.M., (2013). Ankara Numune Eğitim ve Araştırma Hastanesi immünfiksasyon elektroforezi verilerinin değerlendirilmesi.Journal of Clinical and Experimental Investigations., 4:148-152.

[45] Abraham, R.S., Barnidge, D.R., and Lanza, I.R., (2012). Assessment of Proteins of the Immune System. In Clinical Immunology: Principles and Practice: Fourth Edition (pp:11451159 .

[46] Katzmann, J.A., (2009). Screening Panels for Monoclonal Gammopathies: Time to Change. Clin Biochem Rev., 30:105-111.

[47] Dispenzieri, A., Kyle, R., Merlin, i.G., Miguel, J.S., Ludwig, H., and Hajek, R., (2009). International Myeloma Working Group. International Myeloma Working Group Guidelines for Serum-Free Light Chain Analysis in Multiple Myeloma and Related Disorders. Leukemia., 23:215-24.

[48] Zeren, F., Genç, A., and Çürük, M.A., (2007). Preliminary Data on Preimplantion Genetic Diagnosis for Hemoglobinopathies in Turkey, Hemoglobin., 31:273-277.

[49] http://www.medical-labs.net/hemoglobin-electrophoresis.

[50] Michels, D.A., Hu, S., Schoenherr, R.M., Eggertson, M.J., and Dovichi, N.J., (2002). Fully Automated Two-dimensional Capillary Electrophoresis for High Sensitivity Protein Analysis. Mol Cell Proteomics., 1:69-74.

[51] Kristensen, V.N., Kelefiotis, D., Kristense, T., Borresen Dale, A.L., (2001). High Throughput Methods for Detection of Genetic Variation, Bio Techniques., 30:318-332.

[52] Larsen, L.A., Christiansen, M., Vuust, J., and Andersen, P.S., (1999). High Throughput Single Strand Sonformation Polymorphism Analysis by Automated Capillary Electrophoresis: Robust Multiplex Analysis and Pattern Based Identification of Allelic Variants, Human Mutation., 13:318-327.

[53] Chéry, C.C., Moens, L., Cornelis, R., and Vanhaecke, F., (2006). Capabilities and Limitations of Gel Electrophoresis for Elemental Speciation: A laboratory's experience. Pure Appl. Chem., $78: 91-103$.

[54] Ugaz, V.M., Lin, R., Srivastava, N., and Burke, D.T., (2003). Burns M.A.A Versatile Microfabricated Platform for 
Electrophoresis of Double and Single stranded DNA. Electrophoresis., 24:151-7.

[55] Garrels, J.L., (1999). Electrophoresis System. US Patent 5882495.

[56] Sun, W., (2010). General Procedures. In Molecular Diagnostics (pp:49-57). Academic Press.

[57] Burgess, R.R. and Deutscher, M.P., (2009). Methods in Enzymology Guide to Protein Purification, 2nd.

[58] Ahuja, S. and Scypinski, S., (Eds.). (2001). Handbook of Modern Pharmaceutical Analysis (Vol:3). Academic Press.

[59] Basım, E. And Basım, H., (2001). Pulsed-field Gel

Electrophoresis (PFGE) technique and its Use in Molecular Biology. Turkish Journal of Biology, 25(4):405-418.

[60] Pagaduan, J.V., Sahore, V., and Woolley, A.T., (2015). Applications of Microfluidics and Microchip Electrophoresis for Potential Clinical Biomarker Analysis. Analytical and Bioanalytical Chemistry, 407 (23):6911-6922.

[61] Ahuja, S. and Scypinski, S., (Eds.). (2001). Handbook of Modern Pharmaceutical Analysis (Vol:3). Academic Press. 